\title{
Sovyet Propaganda Dergisi Krokodil'de İran İslam Devrimi Sırası ve Sonrasında İran'ın Temsili
}

\author{
Caner Çakı* \& Abdülhakim Bahadır Darı**
}

\section{Öz}

İran şahı Muhammed Rıza Pehlevi'nin iktidarı döneminde Batı yanlısı siyasete yönelmesi, Sovyetler Birliği ve İran arasında yakın ilişkilerin kurulmasını engellemiştir. Diğer yandan 1979 yılında gerçekleşen İran İslam Devrimi'nden sonra kurulan İran İslam Cumhuriyeti'nin Komünizm karşııı bir politika izlemesi nedeniyle de Sovyetler Birliği ve İran arasında yakın ilişsilerin kurulması yine mümkün olmamıştır. Buna karşılık İran şahına karşı gerçekleştirilen İran İslam Devrimi'ni Sovyetler Birliği'nin mizah dergisi Krokodil çeşitli açılardan ele almıştır. Krokodil'in baskı sayısı bakımından Sovyetler Birliği'nin önde gelen mizah dergilerinden birisi olması ve aynı zamanda Sovyetler Birliği'nin propaganda aracı olarak hizmet etmesi nedeniyle Krokodil'deki İran İslam Devrimi'nin sunumu, Sovyetler Birliği'nin İran İslam Devrimi'ne ve sonrasına yönelik siyasi tutumunu yansıtması bakımında önem taşımaktadır. Çalışmada Krokodil'in İran İslam Devrimi sırasında ve sonrasında İran'ı konu alan karikatürleri incelenerek, Sovyetler Birliği'nin İran İslam Devrimi ve sonrası süreçte İran'a yönelik siyasi bakışının ortaya konulması amaçlanmıştır. Bu amaçla Krokodil'in konuya ilişkin karikatürleri, Alman dilbilimci Karl Bühler'in Organon Modeli 1şı̆̆ında göstergebilim yöntemi kullanılarak analiz edilmiştir. Çalışmada elde edilen bulgular ışığında devrimin başlarındaki karikatürlerde şah karşıı İ̀an İslam Devrimi'nin İran'ın ABD'nin etkisinden kurtuluşu olarak sunulduğu buna karşllık ilerleyen süreçte yayınlanan karikatürlerde İran'a yönelik olumsuz bir algının meydana getirilmeye çalışıldığı ortaya çıkarılmıştır. Bu şekilde çalışmada Krokodil özelinde İran'ı konu alan Sovyet mizahının doğrudan Sovyetler Birliği'nin İran'a yönelik dış politikası çerçevesinde şekillendiği sonucuna ulaşılmıştır.

Anahtar Kelimeler: İran, Propaganda, Mizah, İran İslam Devrimi, Sovyetler Birliği.

Dr., Bağımsız Araştırmacı, Ankara, Türkiye, caner_caki@hotmail.com, ORCID: 0000-0002-1523-4649

** Dr. Öğr. Üyesi, Yalova Üniversitesi, İnsan ve Toplum Bilimleri Fakültesi, Yeni Medya ve İletişim Bölümü, Yalova, Türkiye, daribahadir@gmail.com, ORCID: 0000-0003$3525-5823$ 


\title{
The Representation of Iran in the Soviet Propaganda Magazine Krokodil During and After the Islamic Revolution
}

\author{
Caner Çakı* \& Abdülhakim Bahadır Darı**
}

\begin{abstract}
The fact that Iran shah Mohammad Reza Pahlavi carried out pro-Western politics during his rule prevented the establishment of close relations between the Soviet Union and Iran. On the other hand, it was not possible to establish close relations between the Soviet Union and Iran because the Islamic Republic of Iran, which was established after the Iranian Islamic Revolution in 1979, followed an anti-Communist policy. On the other hand, the Iranian Islamic Revolution against the Iranian shah was discussed from various perspectives in the humor magazine Krokodil of the Soviet Union. Since Krokodil was one of the leading humor magazines of the Soviet Union in terms of print count and also served as a propaganda tool for the Soviet Union, the presentation of the Iranian Islamic Revolution in Krokodil is important in that it reflects the political attitude of the Soviet Union towards the Iranian Islamic Revolution and its aftermath. In the study, it was aimed to reveal the political view of the Soviet Union towards Iran during and after the Iranian Islamic Revolution by examining the cartoons of Krokodil about Iran during and after the Iranian Islamic Revolution. For this purpose, the cartoons of Krokodil on the subject were analyzed using the semiotics method in the light of the Organon Model of the German linguist Karl Bühler. In the light of the findings obtained in the study, it was revealed that the anti-shah Iranian Islamic Revolution was presented as the liberation of Iran from the influence of the USA in the cartoons at the beginning of the revolution, while a negative perception towards Iran was tried to be formed in the cartoons published in the following period. In this way, it was concluded in this study that the Soviet humor about Iran, in particular Krokodil, was shaped directly within the framework of the Soviet Union's foreign policy towards Iran.
\end{abstract}

Keywords: Iran, Propaganda, Humor, Iranian Islamic Revolution, Soviet Union.

\footnotetext{
Dr., Independent Researcher, Ankara, Turkey, caner_caki@hotmail.com, ORCID: 0000-0002-1523-4649

** Asst. Prof. Dr., Yalova University, Faculty of Humanities and Social Sciences, New Media and Communication Department, Yalova, Turkey, daribahadir@gmail.com, ORCID: 0000-0003-3525-5823
} 


\section{Giriş}

Siyasi, toplumsal ve ekonomik düzende yaşanan bozulmalarda zayıf, güçlüye karşı mizahı kullanabilmektedir. Diğer yandan mizah mevcut bir düzene karşı insanların özgürlügünü savunabilmekte, bir savunma veya protesto arac1 olarak kullanılabilmektedir (Davulcu, 2015, s. 15). Mizah yoluyla siyasal ve sosyal düzende yaşananlar eleştirilebilmekte ve belirli güç odakları hedef alınarak halkın temel hak ve hürriyetleri ön plana çıkarılabilmektedir. Tüm bu süreçte mizah, resmedilen karikatürlerde insanların zihinlerinde belirli temsillerin oluşmasında önemli bir rol üstlenebilmektedir. Bunun yanında egemen güçlerin elinde siyasal mizahtan belirli ideolojik söylemlerin benimsetilmesinde, belirli kişi veya gurupların yüceltilmesinde ya da itibarsızlaştırılmasında da propaganda amaçlı yararlanılabilmektedir. Bu aşamada Krokodil'de yer alan siyasal mizah, Sovyetler Birliği'nin siyasal propaganda aracı olarak kullanılmış ve Sovyetler Birliği'nin dış ilişkilerinin Sovyetler Birliği halkına yansıtılmasında etkili olmuştur. Krokodil, Sovyetler Birliği siyasetinde 1979 İran İslam Devrimi ve sonraki süreçte İran'ın siyasal mizahtaki temsilinde önemli bir rol üstlenmiştir.

1979 y1lında gerçekleşen İran İslam Devrimi sonucunda İran'da ABD'nin yakın ilişki içerisinde olduğu Pehlevi rejimi çökmüştür. Pehlevi rejiminin çökmesiyle aynı yıl iktidarda din adamları etkili olmuş ve İran İslam Cumhuriyeti kurulmuştur (Esfandiari, 2001, s. 75). Yetkisini Ayetullah Ruhullah Humeyni'den alan yeni devrimci hükümet, eski rejimin siyasi yönelimini hızla tersine çevirmiştir. Önce çokuluslu şirketler, özellikle de Amerikan firmalarının etkinliği sonlandırılmıştır. Biri Hazar Denizi kıyısında Bender Şah yakınlarındaki Sovyetler Birliği sınırına bitişik, diğeri ise Meşhed'in seksen mil güneyindeki dağlarda 1ssız bir yer olan Kabkam'da bulunan Amerikan istihbarat toplama istasyonu kapatılmıştır. İran, silah alımlarını azaltmış ve Basra Körfezi'ndeki polis rolünden çekilmiş, böylece ABD'yi bölgedeki Batı çıkarlarını koruyabilecek güvenilir bir müttefikten mahrum etmiştir (Rubinstein, 1981, s. 599). Tüm bu süreç Sovyetler Birliği'nin Pehlevi rejiminin aksine yeni rejimle yakın ilişkiler kurması ihtimalini ortaya çıkarmıştır. Buna karşılık yeni rejiminin Sovyetler Birliği'ne mesafeli duruşu bu ihtimalin gerçekleşmesini engellemiştir.

Sovyetler Birliği'nin İran İslam Devrimi'ne ve kurulan yeni rejime bak1şının ortaya konulmasında dönemin Sovyet basınının incelenmesi önem 
taşımaktadır. $\mathrm{Bu}$ aşamada Sovyetler Birliği'nin dış politikasına 1şık tutan ve Sovyet rejiminin bir propaganda aracı olarak hizmet eden Krokodil (Крокодил) adlı mizah dergisinin İran İslam Devrimi ve sonrasındaki süreçte İran'a ilişkin yayınlanan karikatürlerinin ele alınmasının dönemin Sovyet basınının ortaya konulmasında önemli bir rol oynayacağı düşünülmektedir.

Sovyetler Birliği ve İran ilişkilerini çeşitli zaman ve konular altında inceleyen akademik çalışmalar bulunmaktadır. Khalilzad (1984), Humeyni İran'ında Sovyet ikilemlerini ele almıştır. Makalede, ilk olarak Moskova'nın İran devrimine tepkileri ve İslam Cumhuriyeti'ne yönelik ilk politikaları değerlendirilmiş, ikinci olarak Moskova'nın neden İran'da daha fazla nüfuz elde edemediği incelenmeye çalışılmıştır.

Roberts (2011), İran'da Sovyetler Birliği politikasını incelemiştir. Makale, Soğuk Savaş'ın başlarında Sovyetlerin Yunanistan, İran ve Türkiye'ye yönelik politikasını incelemiştir. Stalin'in bu ülkelerle ilgili amaçlarının sınırlı ve Avrupa' daki daha önemli hedeflere ikincil olduğunu tartışmıştır.

Hunter (1987), Sovyetler Birliği ve İran İslam Cumhuriyeti’ni incelemiştir. Makalenin ana odak noktası Sovyetler Birliği'nin İslam Cumhuriyeti ile ilişkileri olsa da, bu ilişkilerin tarihsel ve psikolojik bağlamlarına değinmiştir.

Olson (1993), 1924-1925 yıllarında Doğu İran'daki Türkmen isyanı ve Sovyetler Birliği'nin tepkisini ele almıştır. 1924 sonbaharından 1926 baharına kadar Horasan' daki Türkmen isyanının başta Sovyetler Birliği olmak üzere bölgesel ve uluslararası sonuçlarını değerlendirmek çalışmanın amacinı oluşturmuştur.

Fanani (2012), İran'da İslam devriminin dışa aktarımını ve Sovyetler Birliği'ne yönelik tehdidi incelemiştir. Makale, İran'daki İslam Devrimi'nin arka planını ve bağlamını ve bunun ABD, Sovyetler Birliği ve Arap devletleri üzerindeki etkilerini analiz etmiştir.

Mossaki ve Ravandi-Fadai (2018), 1940'ların sonundan 1960'lara kadar İran'da Sovyet kültürel diplomasisini incelemiştir. Çalışmada daha önce incelenmemiş Sovyet arşiv belgeleri ortaya çıkarılarak ve eski diplomatlarla ilk elden görüşmeler yapılarak, Sovyetler Birliği'nin Dünya Savaşı'nı takip eden on y1llar boyunca İran'daki kültürel örgütler ve olaylar arac1l1ğıyla bozulan Sovyet-İran bağlarını yeniden canlandırmak için nasıl firsatlar $\operatorname{aradığı~ele~alınmıştır.~}$ 
Sovyetler Birliği ve İran üzerine gerçekleştirilen akademik çalışmalar incelendiğinde Sovyet basınında İran İslam Devrimi ve sonrasındaki süreçte İran'ın temsili üzerine alanda önemli bir eksikliğin olduğu sonucuna ulaşılmıştır. Mevcut çalışmada İran İslam Devrimi ve sonrasındaki sürecin Sovyet mizahında ne şekilde temsil edildiği incelenerek, mizah dergileri özelinde alandaki boşluğun bir nebze doldurulmasına çalışılmıştır. Bu şekilde Sovyetler Birliği'nin propaganda aracı olarak hizmet eden Krokodil dergisinde yayınlanan karikatürler üzerinden Sovyetler Birliği’nin İran İslam Devrimi ve sonrasındaki süreçte İran'a bakışının ortaya konulması amaçlanmıştır. Bu amaçla çalışma kapsamında Krokodil'in konuya ilişkin karikatürleri göstergebilim yöntemi kullanılarak Sovyetler Birliği'nin mizah propagandası bağlamında analiz edilmiştir. Çalışmada elde edilen bulgular ışığında aşağıda yer alan soruların yanıtlanmasına çalışı1mıştır:

- Krokodil'deki karikatürlerde İran İslam Devrimi ne şekilde temsil edilmektedir?

- Krokodil'deki karikatürlerde İran İslam Devrimi ve ABD arasında nasıl bir ilişki kurulmaktadır?

- Krokodil'deki karikatürlerde İran İslam Devrimi sonrasındaki süreçte yeni rejim nasil yansitılmaktadir?

Çalışma, Sovyetler Birliği'nin mizah propagandasında İran İslam Devrimi ve sonrasındaki süreçte İran'ın nasıl temsil edildiğini ortaya koyması bakımından önem taşımaktadır. Bu açıdan çalışmanın Sovyetler Birliğiİran ilişkileri üzerine çalışmada bulunan siyaset, tarih ve iletişim bilimi alanındaki araştırmacıların yararlanabilecekleri bir kaynak olması amaçlanmaktadır.

\section{2. İran İslam Devrimi Sonrasında Sovyetler Birliği-İran İlişkileri}

İran İslam Devrimi sonrasında İran ve ABD ilişkilerinde radikal değişimler yaşanmış, Pehlevi döneminde müttefiklik ilişkilerine sahip olan iki ülke, Humeyni döneminde iki rakip ülke haline gelmiştir. Diğer yandan İran'ın ABD karşıtı politikaya yönelmesiyle İran ve Sovyetler Birliği ilişkilerinin olumlu yönde gelişme ihtimali ortaya çıkmıştır. Humeyni'nin iktidara gelmesinden sonra Sovyet-İran ilişkilerinde öne çıkan meseleler, Sovyetlerin 
ilişkileri normalleştirme girişimi; Afganistan'ın işgali; Irak-İran Savaş1; doğal gazın fiyatı ve İran'ın iç karışıklığına Sovyet müdahalesi olmuştur (Rubinstein, 1981, s. 602). Tüm bu meseleler Sovyetler Birliği ve İran İslam Cumhuriyeti arasındaki ilişkilerin şekillenmesinde önemli rol oynamiştır.

1979 yılında İran şahının düşüşünden sonra ABD, İran'ın Sovyetler Birliği'ne yöneleceğinden ya da daha kötüsü onun uydusu olacağından çekinmiştir. Diğer yandan Sovyetler Birliği, o sırada İran'da yaygın olan güçlü Amerikan karşıtı duyguların, iki devlet arasında güçlü bir ekonomik ve siyasi ve hatta belki de askeri bir ittifak oluşturmaya yardımcı olacağını ummuştur. Ancak süper güçler hem devrimi değerlendirmelerinde hem de Pehlevi sonrası İran'ı anlamalarında yanılgıya uğramıştır (Tarock, 2017, s. 520). Nitekim Humeyni yönetimi, Pehlevi yönetimi gibi uluslararası ilişkilerde ABD'ye yaklaşmamış, aksine rehine krizi ${ }^{1}$ sürecinde iki ülke ilişkileri belki de tarihinde hiç olmadığı kadar gerilim yaşamıştır. Diğer yandan İran'daki devrim süreci ABD karşıtı söylemleriyle ön plana çıkmasına karşıllk, Sovyetler Birliği' yle yakınlaşmaya yönelik radikal girişimlere de izin vermemiştir. Humeyni'nin teokratik yönetimi, Komünizm ideolojisini benimseyen Sovyetler Birliği’yle mesafeli durmayı tercih etmiştir. Soğuk Savaş'ın devam ettiği bir dönemde gerçekleşen devrimde yeni rejim, uluslararası bloklaşmada ne Batı ne de Doğu Blok'u içerisinde yer almıştır.

İran'ın yeni yöneticilerinin belirgin ABD karşıtı tutumunun yalnızca Washington ile yakın ilişkilerin yeniden başlamasını engellemekle kalmayıp, aynı zamanda Tahran ile Moskova arasında bir yakınlaşmayı da kolaylaştırabileceğine dair üzeri örtülü bir umutla, Kremlin Mehdi Bazargan'ın geçici hükümetini tanımıştır. 3 Mart 1979 tarihinde Sovyetler Birliği devlet başkanı Leonid Brejnev devrimin zaferini memnuniyetle karşılamış ve iyi komşuluk ilişkilerinin verimli bir şekilde gelişeceği umudunu dile getirmiştir. Buna karşılık, devrimci rejim kısa süre sonra İran'ın Sovyetler Birliği ile dostluk kurmaya niyeti olmadığını ortaya koymuştur. Hatta Kasım ayında Tahran, Sovyetler Birliği ile 1921 anlaşmasının sırasıyla İran'ın Sovyetler Birliği'nin güvenliğine tehdit oluşturan yabancı güçlerin mev-

İran Rehine Krizi, 4 Kasım 1979 tarihinde bir grup İranlı üniversite öğrencisinin Tahran'daki ABD Büyükelçiliği'ni ele geçirmesinin ardından 52 kişinin rehin alınma girişimidir. Rehineler, 20 Ocak 1981 tarihinde serbest bırakılmıştır. Rehine krizi, ABD ve İran ilişkilerinin gerginleşmesinde önemli bir rol oynamıştır. 
cudiyetini yasaklayan ve Sovyet birliklerinin İran'a girmesine izin veren 5. ve 6. maddeleri tek taraflı olarak yürürlükten kaldırmıştır. Bu iki maddenin tek taraflı olarak yürürlükten kaldırılmasının emsali 1959 yılında şah tarafindan belirlenmiştir. Buna karş1lık 1959 yılında, 1979 yılında olduğu gibi, Kremlin, Sovyetler Birliği açısından, 1921 Anlaşması'nın bütünüyle yürürlükte kaldığını açıklamıştır (Smolansky, 1981, s. 321). Yeni rejiminin bu tavrı, Sovyetler Birliği'nin ABD'nin yerine İran'ın yeni müttefiki olmasinı engellemiştir.

Moskova-Tahran ilişkileri, 1979 yılının sonlarında Sovyetler Birliği'nin Afganistan'1 işgali sonucunda daha da kötüleşmiştir. İran, hareketi "Doğu'nun sömürgeciliğinin" bir tezahürü olarak kınamış, Sovyet güçlerinin geri çekilmesini talep etmiş ve anti-komünist isyancilara destek için mütevazı bir program başlatmıştır. 1980 yılının başlarında, Afgan direniş gruplarının temsilcileri Pakistan'daki İslam konferansına katılan İran heyetine katılmıştır. İlerleyen süreçte, İran Dışişleri Bakanı Sadegh Ghotbzadeh, Sovyetler Birliği'ni yıkıcı faaliyetlerle suçlamış ve Moskova'ya Tahran Büyükelçiliği' nin boyutunu küçültmesini ve iki eyalet konsolosluğundan birini kapatmasını emretmiştir (Smolansky, 1981, s. 321). Bu aşamada İran yönetimini Sovyetler Birliği’nden uzaklaştıran başlıca faktörler, 1979 yılında Sovyetler Birliği’nin Afganistan'ı işgal etmesi ve İran'da ayrılıkçı hareketi körükleme işine karışması olmuştur. İran ayrıca Sovyet birliklerinin varlığının bölgede süper güçlerin karşı karşıya gelmesine yol açabileceğinden çekinmiştir. İran hükümeti, İslam kardeşliğinin bir jesti olarak, Sovyet tepkisini aldırmadan Afgan mültecilere sığınma hakkı vermiştir. İran, bir milyondan fazla Afgan mülteciye sahip olmuş, farklı vesilelerle Sovyetler Birliği’ne karşı gösteri yapılmıştır. 1982 yılında Tahran'daki Sovyet Büyükelçiliği önünde Afganistan'ın komünist işgalini protesto etmek amac1yla büyük bir Afgan mülteci yürüyüşü gerçekleşmiştir (Akbar, 1988, s. 63-64).

İran-Sovyetler Birliği ilişkilerinde Humeyni'nin 1989 yılının başında Sovyet lideri Mihail Gorbaçov'a yazdığı mektupla tetiklenen dönüm noktası, İran'ın önde gelen isimlerinden biri olan Haşimi Rafsancani'nin Moskova'ya yaptığ tarihi ziyaretle somut bir hale kavuşmuştur. İran Meclis Başkanı'nın Haziran ayındaki ziyareti, İran İslam Devrimi'nin ikinci on yılına girerken İran'ın iç ve dış politikalarındaki dönüşüm sürecini yansıtmıştır. İran'ın Sovyetler Birliği ile ilişkilerindeki atılımı, birbiriyle iliş- 
kili iki faktör motive etmiştir. Bunlar, bölgede barış arzusu ve Tahran'ın ekonomik kalkınma ve yeniden yapılanma programının başarısını sağlama ihtiyacıdır (Irfani, 1989, s. 5). Bu şekilde İran İslam Cumhuriyeti, Sovyetler Birliği’nin son yıllarında iki ülke arasındaki ilişkilerin geliştirilmesine yönelik bir politikaya yönelmiştir.

\section{20. Yüzyılda Siyasi Karikatürlerin Propagandadaki Rolü}

Propaganda, belirli bir fikrin ya da ideolojinin kitlelere benimsetilerek kitlelerin belirlenen hedef doğrultusunda belirli bir düşünce, tutum ya da davranışa sahip olmasının sağlanması amacıyla kitle iletişim araçları kullanılarak gerçekleştirilen ikna odaklı bir iletişim türüdür. Birinci Dünya Savaşı'nda propaganda, rakiplerin birbirlerine üstünlük mücadelesinde kamuoyunu etkilemek, bunun dışında İkinci Dünya Savaşı ve Soğuk Savaş döneminde de ideolojik söylemleri kitlelere benimsetmek için kullanılmıştır. Bu dönemlerde gazeteler, dergiler, posterler, kartpostallar ve pullarda yer alan karikatürler üzerinden gerçekleştirilen propaganda faaliyetlerinde mizahtan etkili bir şekilde yararlanılmıştır. Karikatürler, bir kişinin veya bir grup insanın özelliklerini kolayca tanımlayabilen bir görsel benzerlik oluşturmak için abartı veya çarpıtma kullanabilen sanat eserleridir (Kleeman, 2006, s. 147). Karikatürler üzerinden desteklenen taraf, olduğundan daha güçlü ve daha büyük resmedilerek, kitleler nezdinde yüceltilmeye çalışılabilmektedir. Diğer yandan propaganda amaçlı hazırlanan karikatürlerde, karşıt taraf olduğundan daha güçsüz ve daha küçük resmedilerek savaşın kazanılmasına yönelik kamuoyu motive edilebilmektedir. Ayrıca karikatürlerde karşıt tarafın insanlık suçu işlediğine yönelik çizimlere yer verilebilmekte, bu şekilde kamuoyunda savaşılan tarafa yönelik nefret söylemi gerçekleştirilebilmektedir. Bu nedenle mizah, hem desteklenen tarafın yüceltilmesinde hem de karşıt olan tarafın itibarsızlaştırılmasında önemli bir propaganda işlevi üstlenebilmektedir.

20. yüzyılda siyasal mizah propagandası çeşitli basılı kitle iletişim araçlar1 üzerinden gerçekleştirilmekle birlikte mizah dergilerinin siyasal mizah propagandasında ayrı bir önemi olmuştur. Birinci Dünya Savaşı'nda gerek İtilaf Devletleri gerekse İttifak Devletleri'nde çok sayıda siyasal mizah dergisi devletlerin propaganda amacına hizmet etmiştir. İtilaf Devletleri içerisinde İngiltere'de Punch (1841-1992) ve İtalya'da L'Asino (1892- 
1925), İttifak Devletleri içerisinde de Almanya'da Kladderadatsch (18481944) ve Avusturya'da Kikeriki (1861-1933) ön plana çıkan mizah dergileri olmuştur. İkinci Dünya Savaşı'nda Nazi Almanya'sında Lustige Blätter (1886-1944) ve Fliegende Blätter (1845-1944) mizah dergileri Nazi mizah propagandasının önemli bir ayağını oluşturmuştur. Ayrıca bu iki dergi antisemitist mizah propagandasında da rol oynamıştır. Sovyetler Birliği’nde Nazi Almanya'sının mizah propagandasına karşı Krokodil (1922-2008) dergisi ön plana çıkmıştır. Krokodil, Soğuk Savaş döneminde de Sovyetler Birliği'nin ABD karşıtı mizah propagandasında etkili bir rol üstlenmiştir.

\section{Sovyetler Birliği'nde Mizah Propagandası Bağlamında Mizah Dergisi Krokodil}

Sovyetler Birliği, kuruluşundan itibaren propaganda faaliyetlerinde mizaha önemli bir yer vermiş ve Sovyetler Birliği’nin mizah propagandasında posterler etkin bir şekilde kullanılmıştır. Sovyetler Birliği, hazırlanan çeşitli propaganda posterleri üzerinden Komünist Parti'nin politikaları doğrultusunda Sovyetler Birliği halkına etki etmeye çalışmıştır. Diğer yandan propaganda posterlerindeki mizah üzerinden Sovyetler Birliği’nin düşmanları Sovyet kamuoyunda sert bir şekilde eleştiriye maruz bırakılmıştır. Sovyetler Birliği mizah propagandasını yalnızca posterlerle sınırlı tutmamış bunun yanında periyodik olarak çıkan mizah dergilerinde de mizah propagandasına yer vermiştir. Nitekim 1920'li yıllarda Sovyet Devleti'nin kurucuları tarafından sadece hiciv sinıf mücadelesinin bir silahı olarak ilan edilmekle kalmamış, Vladimir I. Lenin'in kendisi de kitleler için bir mizah dergisi olarak tasarlanan Krokodil'i kurmayı gerekli bulmuştur (Kozin, 2009, s. 222). Bu nedenle Krokodil, Sovyetler Birliği’nin kurulduğu y1l olan 1922 yılında yayın hayatına başlamıştır.

Krokodil, ilk olarak İşçi Gazetesi'ne (Рабочая Газета) ek olarak 1922 y1lında kurulmuş ve haftada bir yayınlanmıştır. Sovyetler Birliği döneminin büyük bölümünde siyasi hiciv tehlikeli olsa da, Krokodil'e siyasi figürleri ve olayları yermek için izin verilmiştir. Krokodil ayrıca kapitalist ülkelerle alay etmiş ve Sovyet sistemine karşı olduğu iddia edilen çeşitli siyasi gruplara saldırmıştır. Resmi Sovyet yayınlarındaki mizah, kontrole tabi tutulmuş ve yönlendirilmiştir. Zaman zaman Krokodil, Sovyet bürokrasisinin sayısız yönlerinden birine düzgün bir şekilde uyan bir hikâye ya 
da karikatür yayınmış, ancak bir kural olarak, buna karşıllk arka planda sansüre sıkı bir şekilde bakan gözle yazılan şakalar oldukça zayıf kalmıştır (Chamberlin, 1957, s. 27). Diğer bir ifadeyle Sovyetler Birliği’ndeki sık1 sansür uygulamasının, Krokodil'deki siyasi mizahın sınırlarını belirlediği ileri sürülebilmektedir. Buna karşıllı zamanının en büyük ve en popüler hiciv dergisi olan Krokodil, iktidar partisi ile halk arasındaki köprülerden biri olmuştur (Mammadov, 2016, s. 40). Bu köprü Sovyetler Birliği'nin siyasi söylemlerinin kitlelere benimsetilmesinde önemli bir görev üstlenmiş̧ir. Diğer yandan Krokodil, Sovyetler Birliği’nin rakiplerine karş1 Sovyetler Birliği halkı nezdinde olumsuz imaj oluşturulmasında da etkili bir propaganda aracı olarak kullanılmıştır. Bu amaçla İkinci Dünya Savaşı sırasında Nazi Almanya'sının Sovyetler Birliği’nin işgal ettiği dönemde Krokodil, Nazi Almanya'sına karşı nefret söylemine yönelmiştir. İkinci Dünya Savaşı'nın ardından başlayan Soğuk Savaş döneminde ise Krokodil'in hedefinde ABD yer almıştır. Krokodil, Sovyetler Birliği'nin rakiplerini mizahi bir dille eleştirerek, Sovyetler Birliği’nin politikalarını kitleler nezdinde meşrulaştırmaya çalışmıştır.

Krokodil'de yabanc1 kültürlerin temsilinde anekdotlar önemli bir rol oynamıştır. Krokodil, ilk kez 1966 yılında anekdot yayınlamaya başlamı̧̧tır. "Sadece Bir Anekdot" başlıklı düzenli bir sütun, her sayıda beş ila on anekdot içermiştir. Bazı anekdotlar yabancı gerçekliklerle, bazı anekdotlar da Rus veya Sovyet gerçekliğinin açık işaretleri olan yerel gerçekliklerle ilgili olmuştur. 1971 yılında "Sadece bir anekdot" sütununun yerini "Farklı enlemlerin gülümsemeleri" almıştır. Derginin her sayısında bu sütun, yalnızca yabancı gerçeklerle ilgili iki ila on sekiz anekdot içermiştir. "Farklı enlemlerin gülümsemeleri” sütununda ayrıca İskoçlar, Amerikalılar (özellikle Amerikalı turistler ve yeni zenginler hakkında), İngilizler, İtalyanlar vb. hakkında çeşitli ulusal/etnik anekdotlar yer almıştır. Dünyanın dört bir yanından birçok ulus veya etnik grup, önemli bir istisna dışında geniş bir şekilde temsil edilmiştir. Nitekim Sovyetler Birliği'nde yaşayanlarla ilgili -örneğin Gürcüler, Çukçiler, Ukraynalılar veya Yahudiler- hiçbir anekdotta yer almamıştır. Bununla birlikte, yalnızca yabancı değil, büyük ölçüde "yerli" olan birçok anekdot da bulunmuştur. Bazen, bireysel anekdotlar yabanc1 kültürlerin belirli algılanan işaretlerini gösterse bile, okuyucuların dikkati herhangi bir yabancı kültürden çok yerel gerçekliğe çekilmiştir (Dementyev, 2009, s. 186-187). Diğer yandan Krokodil, Sovyet halkının yabancı görünme takıntısıyla alay eden çok sayıda karikatür yayınlamıştır (Golubev, 2020, s. 272). 
Sovyetler Birliği'nde Krokodil'in dişında Perets, Mushtum ve Dadzis gibi farklı mizah dergileri de yayınlanmıştır. Buna karşılık Krokodil, Sovyetler Birliği'nin propagandasında ayrı bir öneme sahip olmuştur. Krokodil, Sovyetler Birliği'nin dağılmasından sonra da yayın hayatını devam ettirmiş ve 2008 yılında yayın hayatı son bulmuştur.

\section{Yöntem}

Çalışmada İran İslam Devrimi sürecinde İran'da şah karşıtı isyanların başladığg 1978 yılından, Sovyetler Birliği’nin dağıldığı 1991 yılına kadar geçen toplam 14 yıl içerisinde Krokodil'in İran İslam Devrimi'ni ve sonrasındaki süreci konu alan karikatürleri çalışma kapsamında incelenmiştir. Çalışmada Krokodil'in Sovyetler Birliği' nin dış politikasına 1şıłk tutulan son sayfalarındaki karikatürler özelinde inceleme gerçekleştirilmiştir. Bu aşamada Krokodil'in 1978-1991 yılları arasındaki toplam 504 sayısı incelenmiş ve İran İslam Devrimi'ni ve sonrasındaki süreci doğrudan veya dolaylı olarak ele alan toplam 6 karikatüre ulaşılmıştır. Çalışmada ulaş1lan 6 karikatür, Alman dilbilimci Karl Bühler'in Organon Modeli 1şığında göstergebilim yöntemi kullanılarak analiz edilmiştir. Çalışmada hem karikatürlerdeki görsel ve yazılı göstergelerin propaganda boyutunda açıklanabilmesi hem de karikatürler üzerinden propaganda boyutunda Sovyetler Birliği halkı nezdinde oluşturulmak istenen düşünce ve tutumların yans1tılabilmesi için karikatürlerin göstergebilimsel analizinde Bühler'in Organon Modeli'nin kullanılması kararlaştırılmıştır.

Organon Modeli'nde anlatımsallık, temsil ve istem olmak üzere göstergelerin üç temel işlevi üzerinde durulmaktadır. Anlatımsallık işlevinde iletişimde kaynağın mesajını iletmek amacıyla göstergeleri nasıl konumlandırdığı ele alınmaktadır. Temsil işlevinde, göstergelerin anlamları ortaya konulmakta ve iletişimde göstergeler üzerinden kaynağın alıcıya vermek istediği mesaj/lar incelenmektedir. Son olarak istem işlevinde ise iletişimde kaynağın verdiği mesaj üzerinden alıcıda oluşması istenilen düşünce, tutum ve davranış açıklanmaktadır (Erol, 2020, s. 702). Bühler, bir duyurunun konuşmacı tarafından bir temsil eşdeğeri olarak verilebileceğinin ve dinleyici tarafından kabul edilip değerlendirilebileceğinin kabul edildiğini belirtmektedir (Bühler, 1918, s. 11). Bu aşamada gösterge ya da göstergeler üzerinden kaynak, alıcıya belirli bir temsil ya da temsiller yoluyla 
çeşitli mesaj ya da mesajlar iletebilmektedir. Bühler'in modeli çerçevesinde göstergelerin temsilleri çözümlenmekte ve verilmek istenen mesajlar ortaya konulmaktadır.

Bühler bir resmin ya da haritanın yalan söyleyemeyeceğini, sadece doğruyu ya da yanlışı temsil ettiğini belirtmektedir (Bühler, 1918, s. 11). Göstergelerin temsil ettiği anlamlar insanlar arasındaki uzlaşıyla meydana gelmektedir. Diğer bir ifadeyle bir göstergenin temsili, insanların ona atfettiği anlam üzerinden şekillenmektedir.

Göstergebilim, insan anlamlandırmasının yer aldığı öz-oluşumunun nesnel çerçevelerini oluşturan ve bilgilendiren gösterge konfigürasyon sistemlerini incelemektedir. Algıyı göstergebilimle ilişkilendirmeye yönelik tamamlayıcı yaklaşımlar, gösterge üretiminin bilinçte izlediği yolları ve farklı gösterge sistemlerinin göstergebilimsel güçlerini ve aralarındaki ilişkileri belirleyebilmektedir. Charles Sanders Peirce'in ikon, indeks ve sembol üçlüsü, Karl Bühler'in semptom/indeks, sinyal ve sembol üçlüsü ve Ernst Cassirer'in ifade, temsil ve saf anlam üçlüsü, bu tür analizlerin nasıl gerçekleştirileceğini birbirine bağl1 şekillerde örneklemektedir (Innis, 2020, s. 31). Bu aşamada Bühler'in modelinde göstergelerin anlamlandırılmasının dişında göstergeler yoluyla insanlarda oluşturulmak istenen algı da ön plana çıkmaktadır. Model üzerinden insanların zihinlerinde meydana getirilen algılar ve bu algıların insanların tutumları üzerindeki rolü ortaya konulabilmektedir.

Çalışmada ilk olarak Krokodil dergisinde incelenen karikatürler hakkında temel bilgilere yer verilmiş, ardından karikatürler, Sovyetler Birliği'nin İran İslam Devrimi'ne ve sonrasındaki sürece yönelik propagandası bağlamında sırasıyla Organon Modeli’nin üç temel işlevi üzerinden analiz edilmiştir.

\section{Analiz ve Bulgular}

Çalışmanın bu kısmında Krokodil'in İran İslam Devrimi'ni ve sonrasını konu alan altı karikatür göstergebilim yöntemi kullanılarak incelenmiştir.

\section{1. Birinci Karikatür}

Çalışmada incelenen ilk karikatür, derginin 1979 yılının 4. sayısında Y. Cherepanov'un çizimidir. Karikatür, İran şahının İran'ı terk ettiği tarihten sonra yayınlanmıştır. 
Anlatımsallık işlevi boyutunda incelendiğinde karikatürde burnu uçak gemisine benzetilen sinirli bir şekilde sunulan bir erkek resmedilmektedir. Karikatürde yer alan kişinin başına ABD ordusuna ait bir asker şapkası ve sağ yakasında $U S(\mathrm{ABD})$ yazısı yer almaktadır. Karikatürdeki kişinin burnundaki uçak gemisinde ABD bayrağı bulunmakta ve uçak gemisi şeklindeki burnundan iki uçak havalanmaktadır. Karikatürde havalanan uçakların üstünde Иран (İran) yazan büyük bir anahtar deliğine yöneldiği resmedilmektedir. Anahtar deliğinin içerisinde bina siluetleri ve bina siluetlerinin önünde ise gösteri yaptığı izlenimi veren bir gurup insan yer almaktadır. Diğer yandan bina siluetlerinin arka planında büyük bir alev bulunmaktadir.

\section{Görsel 1}

\section{Birinci Karikatür ${ }^{2}$}

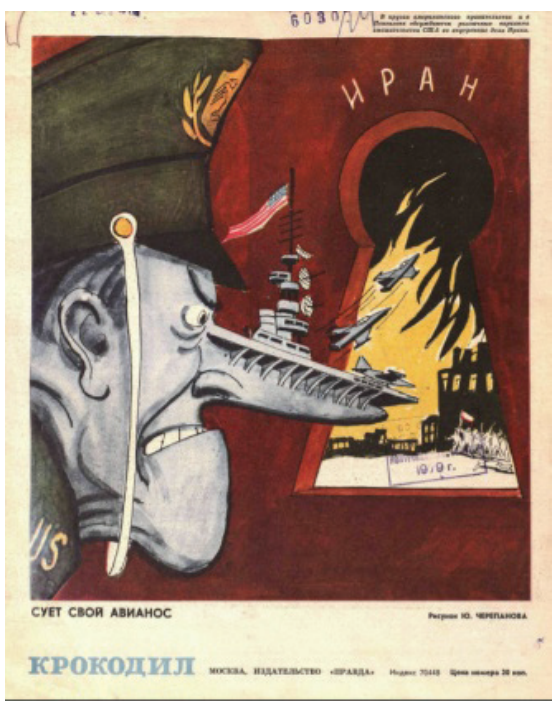

Not. Uçağını İter ve ABD’nin İran İslam Devrimi’ne Müdahale Girişimi. Y. Cherepanov tarafindan "Crocodile"de basılmıştır. Cherepanov, 1979, Crocodile, (4), s. 16. Telif hakk1 [1979] Pravda Yayınevi.

Karikatürün sağ üstünde “Amerikan hükümeti çevrelerinde ve Pentagon'da ABD'nin İran'ın iç işlerine müdahalesi için çeşitli seçenekler tartışılıyor" yazısı ve sol altında ise "Uçağını iter" yazısı yer almaktadır. 
Temsil işlevi açısından ele alındığında karikatürde ABD askeri şapkasından ve ABD bayrağından burnu uçak gemisine benzetilen kişinin ABD'yi simgelediği anlaşılmaktadır. Karikatürde ABD'yi simgeleyen kişinin sinirli olarak sunulmasıyla ABD yönetiminin İran'da şah karşıtı gösterilere karşı olduğu algısı oluşturulmaktadır. Karikatürdeki anahtar deliğinin üstündeki İran yazılı göstergesi üzerinden de bina siluetlerinin önündeki kişilerin, İran şahına karşı ayaklanan göstericilerin metonimi olarak kullanıldığı ortaya çıkmaktadır. Karikatürde ABD bayrağı taşıyan uçak gemisinden havalanan uçakların üstünde İran yazılı anahtar deliğine yönelmesiyle ABD'nin İran'daki şah karşıtı olaylara müdahale ettiğine yönelik mesaj verilmektedir. Karikatürdeki yazılı göstergeler üzerinden de bu mesaj güçlendirilmektedir.

İstem işlevi boyutunda incelendiğinde karikatürde şah yanlılarının İran'da kontrolü kaybetmeye başladığı bir dönemde İran'a yönelik olası bir ABD müdahalesinin gerçekleşeceğine yönelik alg1 oluşturulmaya çalışılmaktadır. Bu aşamada karikatür üzerinden ABD yönetiminin müttefiki İran şahın1 yalnız bırakmayacağı ve İran'daki gösterilere hava kuvvetleriyle müdahale edeceğine yönelik mesaj verilmektedir. Bu şekilde karikatürde ABD, İran'ın iç işlerine karışmakla suçlanmaktadır. Ayrıca karikatürde Pehlevi rejiminin iktidarda kalmasının ABD'nin çıkarlarına hizmet ettiği ön plana çıkarılmaktadır. Karikatürde doğrudan İran'daki şah karşıtı göstericileri destekleyici bir mesaj verilmemekle birlikte şah ve ABD yönetimi arasındaki ilişkilere vurgu yapılarak, Sovyetler Birliği halkı nezdinde Pehlevi rejimine karşı olumsuz bir algı oluşturulmaya çalışılmaktadır.

İran İslami devrimci liderliğinin ABD'ye meydan okuması ve anti-emperyalist politikası, ABD'li politika yapıcılar için büyük bir endişe konusu haline gelmiştir. Bölge Müslümanları için devrimci İran, bölge ülkelerinin iki yüzy1llık sömürge ve yeni sömürge yönetimi sırasında kaybettiği bağımsızlığ1, onuru ve haysiyeti simgelemiştir (Yazdani ve Hussain, 2006, s. 269). Bu aşamada Krokodil'de ABD'nin devrime müdahale edebileceğine yönelik algı oluşturulmasıyla ABD'nin İran'daki çıkarlarının tehdit altında olduğu mesajı verilmektedir. Diğer yandan karikatürde devrimin şah karşıtı boyutunun dışında ABD karşıtı boyutunun üzerinde durulmasıyla dolaylı yoldan devrime yönelik Sovyet kamuoyunda olumlu bir algının oluşmasına yol açılmaktadır. 


\section{2. İkinci Karikatür}

Çalışmada incelenen ikinci karikatür, derginin 1979 y1lının 10. sayısında Bor. Efimova'nın çizimidir. Karikatürün yayınlandığ 1 tarihte İran'da Pehlevi Hanedanlığı çökmüş ve Humeyni yanlısı güçler, İran'a egemen olmaya başlamıştır.

Anlatımsallık işlevi açısından ele alındığında karikatürde devasa boyutta bir erkeğin elinde, üstünde За независимый демократический иран! (Bağımsız, demokratik bir İran için!) yazılı bir pankartı taşıdığı resmedilmektedir. Karikatürdeki erkeğin önünde ipe asılı bir halı bulunmakta ve erkeğin elindeki pankartla önündeki halıyı silkelediğine yönelik bir alg1 meydana gelmektedir. Karikatürde ipe asılı olan halının öteki tarafında ise düşmekte olan, üstünde dolar işareti \$ bulunan bir çanta tutan bir kişi, üstünde Военные Базы (Askeri Üsler) yazısı bulunan bir çanta tutan başka bir kişi, üstünde $\mathrm{CABAK}^{3}$ (SAVAK) yazısı bulunan bir çanta tutan bir diğer kişi, üstünde ЦРУ (CIA) yazan bir çanta ve düşmekte olan diğer üç kişi daha resmedilmektedir.

\section{Görsel 2}

\section{İkinci Karikatür ${ }^{4}$}

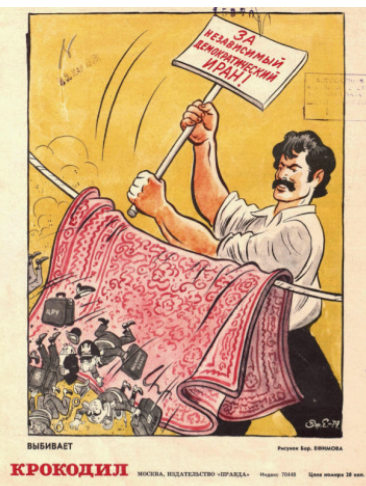

Not. Deviriyor ve İran İslam Devrimi Süreci. Efimova tarafindan

“Crocodile"de basılmıştır. Efimova, 1979, Crocodile, (10), s. 16. Telif hakk1 [1979] Pravda Yayınevi.

SAVAK, Pehlevi hanedanlığı döneminde İran'da 1957-1979 yılları arasında faaliyette bulunan gizli polis, iç güvenlik ve istihbarat servisine verilen isimdir.

4 Karikatürün sol altında "Deviriyor" yazısı bulunmaktadır. 
Temsil işlevi boyutunda incelendiğinde karikatürdeki pankarta yer alan yazılardan pankartı taşıyan kişinin İran'da şah karşıtı ayaklanmaya katılan göstericileri simgelediği anlaşılmaktadır. Diğer yandan halının diğer tarafında bulunan çantaların üstündeki Askeri Üstler, CIA ve SAVAK yazılı göstergeleri üzerinden halının diğer tarafındaki kişilerin de ABD yönetimini ve Pehlevi rejimini temsil ettiği ortaya çıkmaktadır. Karikatürde İran'daki göstericileri simgeleyen kişinin elindeki pankartla halıya vurduğu izlenimi verilerek, İran İslam Devrimi sonucunda ABD yönetiminin ve Pehlevi rejiminin İran'daki etkisini kaybettiği mesajı verilmeye çalışılmaktadır. Karikatürde İran'daki göstericileri simgeleyen kişinin devasa boyutta temsil edilmesiyle İran'daki göstericilerin gücüne vurgu yapılmaktadır.

İstem işlevi açısından ele alındığında karikatürde Pehlevi rejiminin çöktüğüne ve şah karşıtı güçlerin İran'a egemen olmaya başladığına yönelik mesaj verilmektedir. Karikatürde CIA ve SAVAK'ın İran'dan uzaklaştırılmasıyla doğrudan ABD yönetimi ve Pehlevi rejiminin arasındaki yakın ilişki vurgulanmaktadır. Bu şekilde Pehlevi rejiminin çöküşüyle aynı zamanda ABD'nin İran'daki etkisinin son bulduğu algısı oluşturulmaktadır. Karikatürdeki yazılı ve görsel göstergeler bir bütün olarak incelendiğinde karikatürde yer alan pankarttaki demokratik İran söylemiyle İran'daki Pehlevi rejiminin sonlandırılmasına ve bağımsız İran söylemiyle de İran'ın ABD'nin etkisinden uzaklaşmasına yönelik mesaj verilmektedir. Karikatürde devasa boyutta resmedilen kişinin taşıdığı pankart üzerindeki yazıdan İran'daki göstericilerin İran'da bağımsız ve demokratik bir İran için mücadele ettiği vurgulanmaktadır. Böylece karikatür üzerinden Sovyetler Birliği halkı nezdinde İran'daki şah karşıtı göstericilere yönelik olumlu bir alg1 oluşturulmaya çalışılmaktadır.

İran İslam Devrimi'yle birlikte İran siyasetinde yeni bir yola girilmiş ve İran, ABD karşıtı taraf haline gelmiştir (Ekren, 2017, s. 147). Krokodil'in karikatüründe de devrimle İran'ın ABD ile yollarının ayrılmasına değinilmiş ve İran'ın ilerleyen süreçte Sovyetler Birliği ile yakınlaşabileceğine yönelik ihtimalin önü açılmıştır. 


\section{3. Üçüncü Karikatür}

Çalışmada incelenen üçüncü karikatür, derginin 1979 yılının 28. sayısında Bor. Efimova'nın çizimidir. Karikatür, İran İslam Cumhuriyeti'nin kurulmasından sonra yayınlanmıştır. Diğer yandan karikatürün yayınlandığı tarihte İran şahı yurt dişında sürgünde bulunmaktadır. İran şahı, sürgün döneminde çeşitli ülkelerde kalmış ve 27 Temmuz 1980 tarihinde Mısır'da hayatını kaybetmiştir.

Anlatımsallık işlevi boyutunda incelendiğinde karikatürde sırtlarında büyük birer ayak izi olan, valiz taşıyan, birbirlerini şapkalarıyla selamlayan ve havada oldukları izlenimi verilen iki erkek bulunmaktadır. Karikatürdeki erkeklerin birinin üstünde Сомоса (Somosa), diğerinin üstünde ise Шах (şah) yazısı yer almaktadır. Karikatürde üstünde Somosa yazılı kişi, Nikaragua devlet başkanı Anastasio Somoza Debayle ${ }^{5}$ ye, üstünde şah yazan kişi ise İran şahı Muhammed Rıza Pehlevi'ye benzetilmeye çalışılmıştır. Karikatürde üstünde şah yazan kişinin valizinin yanında İran şahının tacı bulunmaktadır. Karikatürdeki her iki kişinin valizinin üstünde dolar işareti \$ yer almakta ve valizlerin içerisinden banknotlar dışarı sarkmaktadır. Karikatürde yer alan kişilerin arasında - Не посоветуете ли, где найти надежное политическое убежище? (Güvenilir bir siyasi sığınma yerinin nerede bulunacağı konusunda tavsiyede bulunabilir misiniz?), - Сам ищу (- Kendim arıyorum) şeklinde diyalogun geçtiği aktarılmaktadır. Karikatürdeki kişilerin aşağısında ise bina görsellerine yer verilmektedir.

Anastasio Somoza Debayle (1925-1980), Nikaragua'da etkili olan Somoza ailesinin devlet başkanı olan son üyesidir. Sandinista Ulusal Kurtuluş Cephesi'nin (FSLN) liderliğindeki isyancıların Managua'ya yaklaşması sonucu Nikaragua'yı terk etmiş ve devlet başkanlığı sona ermiştir. ABD başkanı Jimmy Carter tarafından ABD'de sığınma talebi reddedilen Somoza, daha sonra Paraguay'a sığınmıştır. Somoza'nın mensubu olduğu Somoza ailesi, ABD ile yakın ilişki içerisinde olmuştur. 


\section{Görsel 3}

\section{Üçüncü Karikatür}

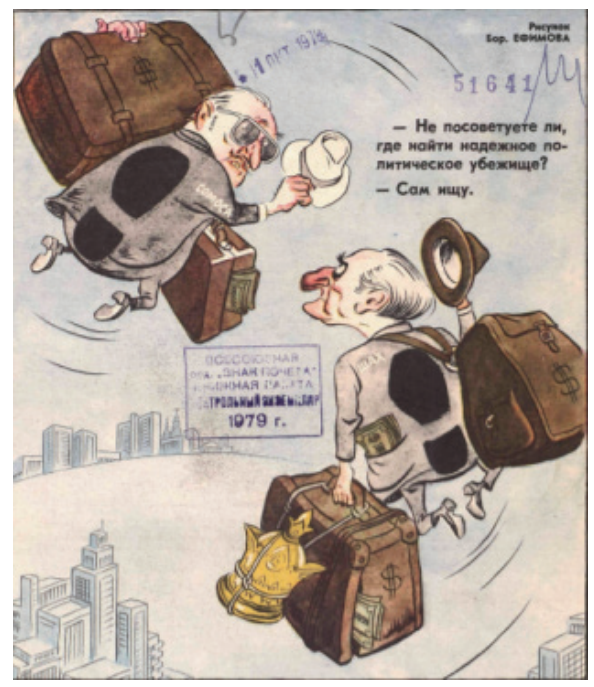

Not. Somoza ve Şah ve Somoza ve Şah'ın Ülkelerini Terk Etmesi. Efimo va tarafindan "Crocodile"de basılmıştır. Efimova, 1979, Crocodile, (28), s. 16. Telif hakk1 [1979] Pravda Yayınevi.

Temsil işlevi açısından ele alındığında karikatürde gerek görsel gerekse yazılı göstergelerden karikatürde yer alan kişilerden birinin Nikaragua devlet başkanı Anastasio Somoza Debayle'yi, diğerinin ise İran şahı Muhammed Rıza Pehlevi'yi temsil ettiği anlaşılmaktadır. Her iki liderin sırtında yer alan ayak izi üzerinden yönetimlerinin devrildiği ve ülkelerinden ayrıldıkları mesajı verilmektedir. Karikatürde her ikisinin de ellerinde üstünde dolar işareti bulunan para dolu çantalar ile resmedilmesi, ülkelerinden yüklü miktarda parayla ayrıldıkları algısını oluşturmaktadır. Somoza ve Pehlevi temsillerinin arasında geçen diyalog üzerinden de her iki devrik liderin de sığınma talebinde bulunacakları ülke aradıklarına yönelik mesaj verilmektedir. Karikatürde devrik liderlerin havada resmedilmesi üzerinden de iki liderin sürgünde olduklarına yönelik algı oluşturulmaktadır.

İstem işlevi boyutunda incelendiğinde karikatürde Somoza ve Pehlevi'nin iktidardan uzaklaştırılma süreçlerinin birbirine benzetildiği ortaya çıkmaktadır. Somoza, iktidarı döneminde ABD ile yakın ilişki içerisinde ol- 
muş, ABD'nin Somoza'ya desteğini çekmesinden sonra da ülkesini terk etmiştir. Karikatürde Somoza gibi ABD yanlısı bir lider olarak vurgulanan Pehlevi'nin halkı tarafından devrildiğine atıfta bulunulmaktadır. Karikatür üzerinden her iki liderin de ülkelerinde istenmediği ve yüklü miktarda paraya sahip olduğu ileri sürülerek, Sovyetler Birliği halkı nezdinde Pehlevi'ye yönelik olumsuz bir algı meydana getirilmeye çalışılmaktadır.

İran şahı, devrim sürecinde 16 Ocak 1979 tarihinde ülkesini terk etmiş ve sürgün döneminde çeşitli ülkelerde bulunmuştur. 1980 yılında da Kahire'de hayatını kaybetmiştir (Buchan, 2013, s. 426). Krokodil'in bu karikatüründe ABD desteğindeki bir liderin, halkı tarafından ülkesinden çıkarıldığı ve sürgün hayatı yaşadığı üzerinde durulmaktadır. Böylece karikatürde Somoza ve şah özelinde $\mathrm{ABD}$ desteğindeki liderlerin buna benzer bir sürece maruz kalabileceğine yönelik mesaj verilmektedir.

\section{4. Dördüncü Karikatür}

Çalışmada incelenen ikinci karikatür, derginin 1981 yılının 2. sayısında B. Starchikov'un çizimidir. Karikatür, Sovyetler Birliği'nin Afganistan'ı işgal etmesinden ve İran-Irak Savaşı'nın başlamasından sonra yayınlanmıştır.

Anlatımsallık işlevi açısından ele alındığında karikatürde ağaca asılı büyük bir arı kovanı ve içerisinde yarı insan yarı arı şeklinde silah taşıyan canlıların çıktığı resmedilmektedir. Karikatürde yer alan kovanın üstünde Пакистан (Pakistan) yazısı yer almaktadır. Diğer yandan karikatürün çevresinde bulunan üç canlı, üstünde в Индию (Hindistan'a), в Афганистан (Afganistan'a) vе в Иран (İran'a) yazan ve içinde silahlar bulunan çantalar taşımaktadır. Karikatürde yer alan canlıların bazıları sakallı ve sarıklı, bazıları ise yüzü maskeli olarak resmedilmektedir. 


\section{Görsel 4}

\section{Dördüncü Karikatür ${ }^{6}$}

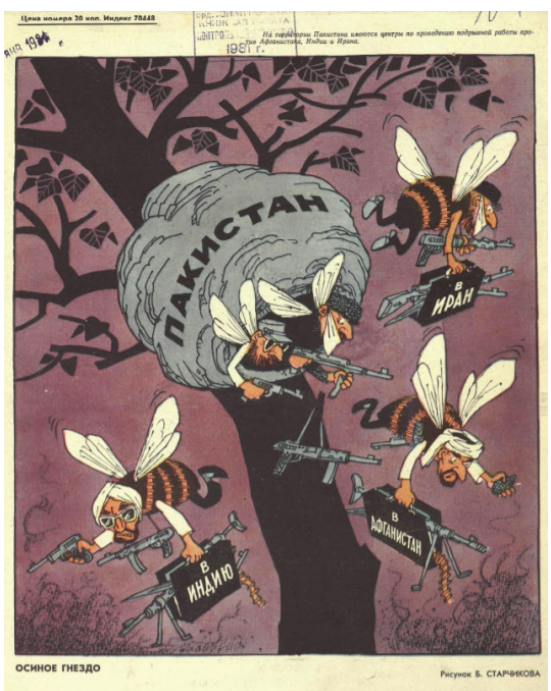

Not. Eşek Arısı Yuvası ve Pakistan, İran, Afganistan ve Hindistan. Starchi kov tarafindan "Crocodile"de basılmıştır. Starchikov, 1981, Crocodile, (2), s. 16. Telif hakk1 [1979] Pravda Yayınevi.

Temsil işlevi boyutunda incelendiğinde karikatürde eşek arısı yuvası yazılı göstergesi üzerinden Pakistan'ın eşek arısı yuvasına benzetildiği anlaşılmaktadır. Diğer yandan yine karikatürde yer alan yazılı gösterge üzerinden arı kovanından çıkan yarı insan yarı arı şeklindeki canlıların ise taşıdıkları silahlardan silahlı eylemlere katılan kişileri temsil ettiği ortaya çıkmaktadır. Karikatürdeki canlıların taşıdığı çantaların üstünde yazan Hindistan' $a$, Afganistan 'a ve İran'a yazılarından Pakistan'dan Hindistan'a, Afganistan'a ve İran'a silah taşındığına yönelik mesaj verilmektedir. Karikatürdeki yaz1lı gösterge üzerinden de taşınan bu silahların ismi geçen bu üç ülkede y1kıcı eylemlerde kullanıldığına yönelik algı oluşturulmaktadır. Karikatürde Pakistan'1 temsil eden arı kovanı tehdit metaforu olarak yansitılmaktadır. $\mathrm{Bu}$ açıdan karikatürde Pakistan tehdit olarak sunulurken, aynı zamanda

6 Karikatürün sağ üstünde "Pakistan topraklarında Afganistan, Hindistan ve İran'a karş1 yıkıcı çalışma merkezleri var" yazısı ve sol altında "Eşek arısı yuvası" yazısı bulunmaktadir. 
Pakistan üzerinden gönderilen silahlarla Hindistan, Afganistan ve İran'ın da tehdit oluşturduğuna yönelik algı meydana getirilmektedir.

İstem işlevi açısından ele alındığında karikatürün Sovyetler Birliği'nin Afganistan'1 işgalinden sonra yayınlanması önem taşımaktadır. Sovyetler Birliği, Afganistan'ı işgal ettiğinde belirli bir muhalif gurup Sovyetler Birliği'ne karşı mücadeleye girişmiştir. Bu mücadele sürecinde muhalifler, Pakistan'dan destek almıştır. Karikatür üzerinden Sovyetler Birliği'nin Afganistan'da mücadele ettiği muhaliflerin Pakistan'da silahlandığı ileri sürülmektedir. Karikatürde benzer şekilde Afganistan gibi Hindistan ve İran'ın da Pakistan üzerinden silahlandığı ileri sürülmektedir. Diğer bir deyişle karikatürde, Afganistan'da Sovyetler Birliği'ne karşı tehdit oluşturan muhaliflerle İran ve Hindistan'ın benzer şekilde sunulduğuna yönelik alg1 oluşmaktadır. Bu süreçte karikatür üzerinden Sovyetler Birliği’nde İran karşıtı bir kamuoyunun meydana gelmesine yol açılmaktadır.

Afganistan'daki Sovyet müdahalesi, İran hükümetini bölgede gelecekteki Rus genişlemesi konusunda alarma geçirmiştir (Akbar, 1988, s. 63). Afganistan'ın işgali konusunda İran ve Sovyetler Birliği arasındaki karşıtlığın meydana geldiği süreçte Krokodil, İran'ı doğrudan bir tehdit olarak ön plana çıkarmıştır.

\section{5. Beșinci Karikatür}

Çalışmada incelenen ikinci karikatür, derginin 1981 yılının 14. sayısında Vladimir Uborevich-Borovsky'nin çizimidir. Karikatür, İran-Irak Savaşı'nın devam ettiği bir sırada yayınlanmıştır.

Anlatımsallık işlevi boyutunda incelendiğinde karikatürde sol kolunun üstünde US (ABD) yazan devasa boyutta bir askerin elleriyle petrol bölgesinin çevresine füzeler yerleştirdiği resmedilmektedir. Karikatürdeki askerin ağzında bir gaz maskesi ve gaz maskesinin ucunda da petrol bölgesine uzanan büyük bir hortum bulunmaktadır. Petrol bölgesinin arka planında ise üstünde Персидский ЗАЛИВ (Basra Körfezi) yazısı yer alan bir deniz kıyıs1 resmedilmektedir. 


\section{Görsel 5}

\section{Beşinci Karikatür ${ }^{7}$}

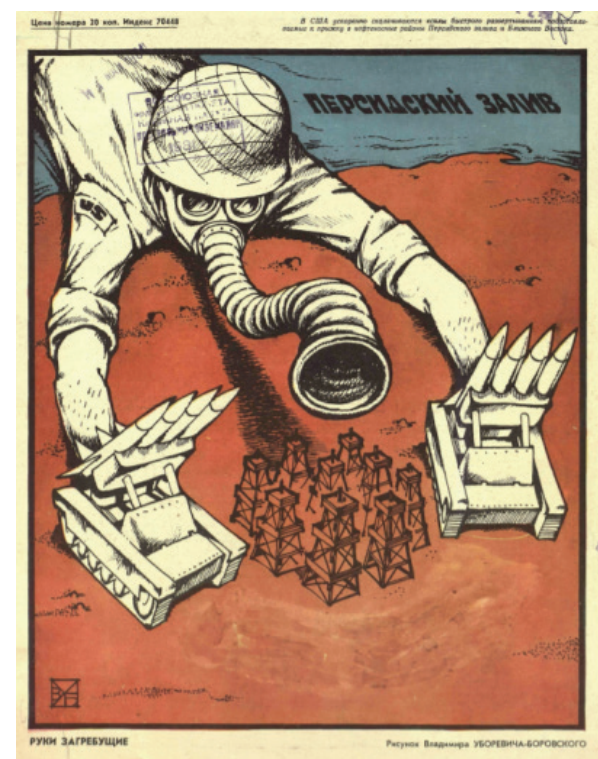

Not. Eller Çıkarma ve İran-Irak Savaşı. Uborevich-Borovsky tarafindan "Crocodile"de basılmıştır. Uborevich-Borovsky, 1981, Crocodile, (14), s. 16. Telif hakk1 [1979] Pravda Yayınevi.

Temsil işlevi açısından ele alındığında karikatürde sol kolunun üstünde $A B D$ yazan askerin, $\mathrm{ABD}$ 'yi simgelediği anlaşılmaktadır. Diğer yandan karikatürdeki yazılı göstergeler üzerinden Orta Doğu'daki petrol tesislerinin metonimi kullanıldığı ortaya çıkmaktadır. Karikatürdeki askerin elleriyle petrol tesislerine füze yerleştirmesi üzerinden ABD'nin Orta Doğu'daki petrol tesisleri üzerinde kontrol kurma çabası içerisinde olduğuna yönelik mesaj verilmektedir.

İstem işlevi boyutunda incelendiğinde karikatürde İran-Irak Savaşı sürecinde Basra Körfezi'ndeki petrol tesislerinin konumu ele alınmaktadır. Krokodil'in İran-Irak Savaşı sürecindeki karikatürleri incelendiğinde, der-

Karikatürün sağ üstünde “Amerika Birleşik Devletleri'nde, Basra Körfezi ve Orta Doğu'nun petrol taşıyan bölgelerine firlatılmaya hazırlanan 'hızlı konuşlandırma gücü' hızla toplanıyor" yazısı ve sol altında "elleri çıkarma" yazısı bulunmaktadır. 
ginin savaş sırasında İran'a yönelik destekleyici bir söyleme yer vermediği ortaya çıkmaktadır. Buna karşı1ık yayınlanan karikatür üzerinden İran-Irak Savaşı'nın ABD'nin bölgesel çıkarları açısından önem taşıdığına vurgu yapılmaktadır.

Sovyetler Birliği’nin İran teokrasisine karşı ideolojik düşmanlığı ön plana çıkmış, Sovyet basınının Humeyni'nin İslam Cumhuriyeti'ni "ilerici” olarak övdüğü 1979 başlarındaki söylemden uzaklaşılmıştır. Diğer yandan Sovyetler Birliği, İran'ın İslami yayılmacılığını ciddi bir sorun olarak değerlendirmiş̧tir (Segal, 1988, s. 962). Bu süreçte Krokodil, savaşa ilişkin ne ABD'nin desteğini arkasına alan Irak'1 ne de kendisine tehdit olarak değerlendirdiği İran'1 konu edinmemiş ve doğrudan savaş sürecinde ABD karşıtı bir algının oluşmasına yol açmıştır.

\section{6. Altıncı Karikatür}

Çalışmada incelenen ikinci karikatür, derginin 1987 yılının 6. sayısında E. Zhivotova ve S. Tsvetkova'nın çizimidir. Karikatür, 1986 yılında İranKontra Skandalı'ndan sonra yayınlanmıştır. Skandal, ABD'deki bazı yöneticilerin İran'a silah satması ve silah satışından elde edilen gelirin Nikaragua'daki kontraları finanse etmek için kullanılmasının planlanmasını içermektedir. Buna karşılık ileri sürülen olayın varlığg ABD tarafından inkâr edilmiştir.

Anlatımsallık işlevi açısından ele alındığında karikatürde geceleyin İran mimarisini yansıtan binaların önünde eşeğe binmiş, yüzü maskeli ve üstünde US (ABD) yazısı bulunan silindir bir şapka giyen bir kişi resmedilmektedir. Karikatürdeki kişi, bir paket taşımakta ve paketin içerisinden uçları sivri nesneler dışarı çıkmaktadır. Sivri nesnelerden birinin üstünde $U S$ (ABD) yazısı bulunmaktadır. Karikatür, geceyi yansıttığı için karikatürde yer alan kişi, bindiği eşek ve taşıdığı paket siyah olarak resmedilmektedir. 


\section{Görsel 6}

\section{Altıncı Karikatür ${ }^{8}$}

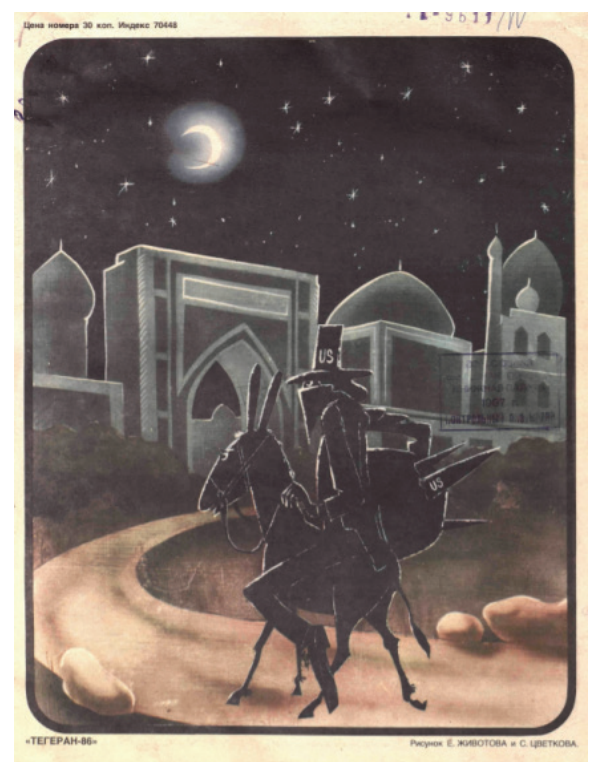

Not: Tahran 86 ve ABD-İran İlişkileri. Zhivotova ve Tsvetkova, tarafindan "Crocodile"de basılmıştır. Zhivotova ve Tsvetkova, 1987, Crocodile, (6), 16. Telif hakk1 [1979] Pravda Yayınevi.

Temsil işlevi boyutunda incelendiğinde karikatürde İran mimarisini yansıtan evlerin, karikatürdeki Tahran 86 yazılı gösterge üzerinden Tahran'ın metonimi olarak kullanıldığ 1 anlaşılmaktadır. Karikatürdeki eşek sırtındaki kişinin şapkasındaki $A B D$ yazısından da eşek sırtındaki kişinin, ABD'yi temsil ettiği anlaşılmaktadır. Karikatürün hazırlandığı bağlam içerisinde değerlendirildiğinde de eşek sırtındaki kişinin taşıdığı, üstünde $A B D$ yazısı olan sivri nesnelerin silah olduğu ortaya çıkmaktadır. Karikatürde ABD'yi temsil eden kişinin gece vakti ve yüzü maskeli olarak silah taşıması üzerinden de İran'ın ABD'den gizlice silah aldığı mesajı verilmektedir.

İstem işlevi açısından ele alındığında karikatürde İran-Kontra Skandalı'nın konu edildiği ortaya çıkmaktadır. Skandal her ne kadar ABD yönetimi ta-

8 Karikatürün sol altında "Tahran 86 ” yazısı yer almaktadır. 
rafından kabul edilmese de karikatür üzerinden İran'ın ABD'den silah aldığı ortaya konulmaktadır. Bu şekilde karikatür üzerinden İran yönetiminin, ABD ile gizlice bağlantı kurduğuna yönelik mesaj verilmektedir. $\mathrm{Bu}$ alg1 üzerinden de Sovyetler Birliği halkı nezdinde İran'ın Pehlevi rejimi gibi ABD ile yakınlaştığına yönelik algı oluşturulmaya çalışıldığı belirtilebilmektedir.

ABD başkanı, bu satışın İranlı 1lımlılar ile ABD-İran ilişkilerini geliştirmeye yardımcı olacağını ve Sovyetler Birliğgi'nin $A B D$ ve müttefikleri için çok büyük stratejik öneme sahip bir ülke olan İran'ın kontrolünü ele geçirmesini önleyecek stratejik bir açılımı oluşturacağını ummuştur (Timbers, 1990, s. 35). Bu aşamada Krokodil, İran-Kontra Skandalı'nı konu edinerek her ne kadar gizli olarak yürütüldügü ileri sürülen bir durumdan dolayı ABD'ye yönelik olumsuz bir algının oluşmasına neden olurken aynı zamanda karşı taraf olan İran'a yönelik de olumsuz bir algının meydana gelebilmesine yol açmaktadır.

\section{Sonuç}

Krokodil'in İran İslam Devrimi'ni konu alan karikatürleriyle İran İslam Devrimi sonrasındaki süreçte İran'1 konu alan karikatürleri arasında önemli bir farklılığın olduğu ortaya çıkarılmıştır. Krokodil, İran şahına karşı gerçekleştirilen devrimi, İran'ın ABD'nin etki alanından kurtularak bağımsız bir şekilde hareket etme süreci olarak değerlendirmiştir. Bu aşamada İran şahının ABD ile olan ilişkilerine vurgu yaparak Pehlevi rejimi ve $\mathrm{ABD}$ arasındaki yakın ilişki ön plana getirilmiştir. Buna karşılık Krokodil, devrimden sonraki süreçte kurulan yeni rejime karşı mesafeli durduğu ve hatta yeni rejimin Sovyetler Birliği halkı nezdinde olumsuz algılanmasına yol açacak karikatürlere yer verdiği ortaya çıkarılmıştır. İran İslam Devrimi'nden sonra Krokodil'in karikatürlerinde yeni rejim hem tehdit olarak yansitılırken hem de yeni rejimin Pehlevi yönetimi gibi ABD ile ilişki içerisinde olduğu ileri sürülmüştür.

Çalışmada elde edilen bulgular genel olarak değerlendirildiğinde Krokodil özelinde Sovyetler Birliği'nin İran İslam Devrimi ve sonrasındaki süreçte İran'a yönelik mizah propagandasının, doğrudan Sovyetler Birliği’nin İran ile olan siyasi ilişkileri çerçevesinde şekillendiği ortaya çıkmıştır. Pehlevi döneminde İran, ABD'nin Orta Doğu'daki önde gelen müttefiklerinden 
biri olmuş, bu nedenle İran ve Sovyetler Birliği arasında yakın ilişkiler kurulamamıştır. İran İslam Devrimi sürecinde İran'ın ABD'den uzaklaşması ve yeni rejiminin ABD karşıtı aldığı kararlar, dolaylı olarak Sovyetler Birliği ve İran'ın birbirine yakınlaşmasının önünü açmıştır. Çalışmada bu süreç, Krokodil'in karikatürlerine doğrudan yansıtılmış ve Krokodil'de İran İslam Devrimi ile İran'ın ABD'den uzaklaşarak bağımsız bir ülke haline gelmeye çalıştığına yönelik propagandaya yer verilmiştir. Buna karşılık yeni rejimin Sovyetler Birliği ile mesafeli olması ve Sovyetler Birliği’nin Afganistan'ı işgali iki ülkenin yakınlaşma sürecini engellemiştir. Yeni rejimin Sovyetler Birliği'ne yönelik temkinli bir siyaset izlemesi, Krokodil'in karikatürlerinde İran İslam Devrimi'nden sonra yeni rejime yönelik olumlu bir imajın oluşmasına izin vermemiştir. Ayrıca Sovyetler Birliği’nin Orta Doğu'daki çıkarlarını doğrudan etkileyen İran-Irak Savaşı sürecinde bile Krokodil'in yalnızca ABD'yi gündeme taşımakla yetinmiş ve İran'ın ABD destelikli Irak güçlerine yönelik mücadelesi konu edilmemiştir. Diğer yandan İran-Kontra Skandalı gibi İran'ın uluslararası alanda imajını olumsuz yönde etkileyebilecek iddia Krokodil sayfasında konu edinmiştir.

Çalışma, Sovyetler Birliği basınının İran İslam Devrimi ve sonrasındaki süreçte İran'a bakışını yansıtarak, hem Sovyetler Birliği ve İran boyutunda uluslararası ilişkiler literatürüne hem de Krokodil özelinde Sovyetler Birliği'nin mizah propagandası bağlamında iletişim bilimleri literatürüne katkı sağlaması bakımından önem taşımaktadır. Propaganda ve karikatür konusunda yapılan çalışmalar çerçevesinde bu çalışma, uluslararası ilişkiler boyutunda karikatürlerin propagandadaki rolünü yansıtmıştır. Bu şekilde Sovyetler Birliği’nin İran İslam Devrimi’ne ve İran İslam Cumhuriyeti’ne yönelik bakışına propaganda karikatürleri üzerinden 1şık tutulmuştur.

Çalışmada kullanılan yöntem üzerinden karikatürler aracılığıyla kamuoyunun istenilen amaçlar doğrultusunda ne yönde şekillendiği ortaya konulmuştur. Çalışmanın yöntemi, karikatürlerdeki görsel ve yazılı göstergeler üzerinden Sovyetler Birliği yönetiminin İran İslam Devrimi ve sonrasındaki süreçte İran yönetimine yönelik Sovyetler Birliği kamuoyunda inşa etmek istediği algıların kapsamlı bir şekilde açıklanmasını sağlamıştır. Alanda konuya ilişkin yapılan çalışmalarda Sovyetler Birliği ve İran ilişkilerinin politika ve diplomasi boyutu ele alınırken, mevcut çalışma iki ülke ilişkilerini Sovyetler Birliği'nin penceresinden basın üzerinden açıklamaya çalışmıştır. Çalışma, Sovyetler Birliği'nin basın yoluyla İran İslam 
Devrimi'ne ve sonraki süreçte İran'a yönelik algısının Sovyet kamuoyuna yansımasını irdelemiştir. Çalışmada Krokodil, İran İslam Devrimi sürecinde İran'1 ABD'nin etkisinden özgürleşmiş şekilde sunmuştur. Buna karş1lı devrimden hemen sonraki süreçte Sovyetler Birliği ve İran ilişkileri arasındaki mesafenin sürmesi, dergide İran'a yönelik olumlu bir imajın oluşturulmasını engellemiştir. Dergi üzerinden İran, Pakistan ve Afganistan gibi Sovyetler Birliği'ne tehdit potansiyeli olan bir ülke ya da İranKontra Skandalı üzerinden ABD ile gizli bir bağlantı içerisinde olan bir ülke olarak sunulmuştur.

Çalışmada Sovyetler Birliği basınının İran İslam Devrimi ve sonrasındaki süreçte İran'a bakışı, mizah dergileri özelinde propaganda boyutunda incelenmiş̧ir. Gelecek çalışmaların, konuya ilişkin Sovyet basınını mizah dergilerinin dışında Pravda (Правда), Komsomolskaya Pravda (Комсомольская правда) ve Izvestia (Известия) gibi dönemin Sovyet gazeteleri üzerinden de ele almasının Sovyetler Birliği’nin İran İslam Devrimi ve sonrasındaki süreçte İran'a bakışının daha kapsamlı olarak ortaya konulmasını sağlayabileceği düşünülmektedir.

Sovyetler Birliği’nin yıkılmasından sonra Rusya ve İran ilişkileri olumlu yönde gelişmiş, İran'ın ABD karşıtlığı İran yönetimini Rusya ile yakınlaştırmıştır. Bu açıdan gelecek çalışmaların Sovyetler Birliği'nin yıkılmasından sonra Rus basınında İran'ın temsilini, mevcut çalışmadaki bulgularla karşılaştırmalı olarak ele alması, Sovyetler Birliği ve Sovyetler Birliği sonrası Rusya'nın İran'a yönelik bakışının karşılaştırmalı olarak ortaya konulmasını sağlayacaktır. Özellikle gelecek çalışmaların Rus basınında İran'ın temsilini yaşanan siyasal gelişmeler bağlamında ele almasının, mevcut çalışmanın sınırlı alanda incelediği basındaki Rusya-İran ilişkilerinin daha geniş bir zaman dilimi içerisinde açıklanmasını sağlayabileceği düşünülmektedir. $\mathrm{Bu}$ açıdan mevcut çalışmanın geçmişten günümüze Rusya ve İran ilişkilerinin medyadaki temsilinde yaşanan değişime sşık tutulmasında önemli bir rol oynaması söz konusu olabilmektedir. 


\section{Beyan}

Bu makaleye her iki yazar eşit katkı sağlamıştır. Makale etik kurul kararından muaftır. Çalışmada katılımcı bulunmamaktadır. Çalışma için herhangi bir kurum veya projeden mali destek alınmamıştır. Çalışmada kişiler ve kurumlar arası çıkar çatışması bulunmamaktadır. Telif hakkına sebep olacak bir materyal kullanılmamıştır.

\section{Disclosure}

Both of the authors contributed equally to this article. The article is exempt from the Ethics Committee Decision. There are no participants. The author received no financial support from any institution and there's no conflict of interest. No material subject to copyright is included. 


\section{Kaynakça}

Buchan, J. (2013). The Iranian Revolution of 1979. Asian Affairs, 44(3), 418-426, https://doi.org/10.1080/03068374.2013.826016

Bühler, K. (1918). Kritische musterung der neuen theorien des Satzes. Indogermanisches Jahrbuch, 6, 1-20. https://pure.mpg.de/rest/items/ item_2304854_2/component/file_2304853/content

Chamberlin, W. H. (1957). The "anecdote": unrationed Soviet humor. Russian Review, 16(3), 27-34, https://doi.org/10.2307/125941

Cherepanov, Y. (1979). Uçağını iter, Crocodile, (4), 1-16. https://tinyurl. com $/ 5 \mathrm{n} 7 \mathrm{n} 83 \mathrm{~h} 7$

Davulcu, E. (2015). 1950'li y1llarda Kayseri'de yayınlanan mizah gazeteleri ve bu gazetelerin yazılarında siyasi-idari ve ekonomik hayat. Erciyes Illetişim Dergisi, 4(1), 14-34, https://doi.org/10.17680/akademia. v4i1.5000046296

Dementyev, V. V. (2009). Russian anekdots of 1970s: on the material of the Soviet humorous journal "Krokodil". Russian Journal of Communication, 2(3-4), 185-198. https://doi.org/10.1080/19409419.2009.10 756750

Efimova, B. (1979a). Deviriyor, Crocodile, (10), 1-16. https://tinyurl. com/mtsceh59

Efimova, B. (1979b). Somoza ve Şah, Crocodile, (28), 1-16. https://tinyurl.com/2p8c3kyp

Ekren, A. (2017). 1979-1995 İran-ABD ilişkileri. Bilecik Şeyh Edebali Üniversitesi Sosyal Bilimler Dergisi, 2(1), 146-155, https://doi. org/10.33905/bseusbed.309765

Erol, E. G. (2020). Nazi Almanya'sında yayıncılık, Nazizm ideolojisinin yaydığı anti-semitist söylemlerin inşası ve kitapların propaganda amaçlı kullanımı. Türk Kütüphaneciliği, 34(4), 693-722, https://doi. org/10.24146/tk. 818460

Esfandiari, H. (2001). The politics of the "women's question" in the Islamic Republic, 1979-1999. İçinde J. L. Esposito, R. K. Ramazani (Ed.), Iran at the crossroads (s. 75-92). Palgrave Macmillan, https:// doi.org/10.1007/978-1-137-07175-0_5 
Fanani, A. F. (2012). The export of Islamic revolution in Iran and its threat for the US, the Soviet Union, and Arab countries. Afkaruna: Indonesian Interdisciplinary Journal of Islamic Studies, 8(1), 1-13, https:// doi.org/10.18196/aiijis.2012.0001.1-13

Golubev, A. (2020). The western observer and the western gaze in the affective management of Soviet subjectivity. Russian Social Science Review, 61(3-4), 251-280. https://doi.org/10.1080/10611428.2020.17 78414

Hunter, S. T. (1987). The Soviet Union and the Islamic Republic of Iran. İçinde, H. Malik (Ed.), Soviet-American relations with Pakistan, Iran and Afghanistan (s. 244-266). Palgrave Macmillan, https://doi. org/10.1007/978-1-349-08553-8_12

Innis, R. E. (2020). Semiotic framing of thresholds of sense. İçinde, Between philosophy and cultural psychology (s. 31-48). Springer, Cham, https://doi.org/10.1007/978-3-030-58190-9_3

Irfani, S. (1989). Iran-Soviet relations. Strategic Studies, 13(1), 5-8, https://www.jstor.org/stable/45181978

Khalilzad, Z. (1984). Soviet dilemmas in Khomeini's Iran. Australian Journal of International Affairs, 38(1), 1-8, https://doi. org/10.1080/10357718408444828

Kleeman, G. (2006). Not just for fun: Using cartoons to investigate geographical issues. New Zealand Geographer, 62(2), 144-151, https:// doi.org/10.1111/j.1745-7939.2006.00057.x

Kozin, A. (2009). "Krokodil" in transition: the case of bureaucrat cartoons. Russian Journal of Communication, 2(3-4), 215-233. https://doi. org/10.1080/19409419.2009.10756752

Mammadov, R. (2016). "The king is dead, long live the king!": image of the United States as the primary enemy on the pages of Krokodil from Stalin to Khrushchev. Visual Communication Quarterly, 23(1), 39-52. https://doi.org/10.1080/15551393.2015.1130591

Mossaki, N., \& Ravandi-Fadai, L. (2018). A guarded courtship: Soviet cultural diplomacy in Iran from the late 1940s to the 1960s. Iranian Studies, 51(3), 427-454, https://doi.org/10.1080/00210862.2018.1436 402 
Olson, R. (1991). The Turkoman rebellion in Eastern Iran, 1924-5: Its consequences and the Soviet reaction. Die Welt des Islams, (2), 216227. https://doi.org/10.2307/1570580

Roberts, G. (2011). Moscow's Cold War on the periphery: Soviet policy in Greece, Iran, and Turkey, 1943-8. Journal of Contemporary History, 46(1), 58-81, https://doi.org/10.1177/0022009410383292

Segal, D. (1988). The Iran-Iraq war: a military analysis. Foreign Affairs, 66(5), 946-963, https://doi.org/10.2307/20043572

Starchikov, B. (1981). Eşek arısı yuvası, Crocodile, (2), 1-16. https://tinyurl.com/2p9e2a34

Tarock, A. (2017). Russo-Iranian relations in the post-Soviet era. Diplomacy \& Statecraft, 28(3), 518-537, https://doi.org/10.1080/09592296 .2017 .1347449

Timbers, E. (1990). Legal and institutional aspects of the Iran-Contra Affair. Presidential Studies Quarterly, 20(1), 31-41, https://www.jstor. org/stable/20700112

Uborevich-Borovsky, V. (1981). Eller çıkarma, Crocodile, (14), 1-16. https://tinyurl.com/2wwvw2fz

Yazdani, E., \& Hussain, R. (2006). United States' policy towards Iran after the Islamic revolution: an Iranian perspective. International Studies, 43(3), 267-289, https://doi.org/10.1177/002088170604300302

Zhivotova, E. \& Tsvetkova, S. (1987). Tahran 86, Crocodile, (6), 1-16. https://tinyurl.com/ym5mk5mr 